\title{
O deserto, a sede, a vida: diálogo entre a teologia e a poesia de João Cabral de Melo Neto
}

\author{
Maria Clara Lucchetti Bingemer
}

\section{Resumo}

Pontifícia Universidade Católica do Rio de Janeiro.

O deserto é uma metáfora muito importante e presente na vida e na experiência espiritual da Bíblia. A dureza geográfica e a sede real dos que atravessam regiões desérticas e secas encontra seu correlato na sede que o ser humano tem de vida em situações de injustiça e opressão. Este artigo procura reunir e fazer dialogar esses elementos ao examinar alguns textos bíblicos e a poesia de João Cabral de Melo Neto, escritor e diplomata brasileiro que este ano celebra centenário. O poema dramático, Morte e Vida Severina será o texto do escritor por nós analisado. Analisamos o poema em si mesmo, comentando alguns de seus versos que mostram uma progressão de Severino pelo deserto espacial que habita em busca de vida, que finalmente se revela na epifania da vida nova do outro, que nasce e invade a desesperança e a morte. Procuraremos concluir trazendo algumas reflexões que a teologia latino-americana tem feito nas últimas décadas sobre os temas trabalhados pela poesia de João Cabral e aterrissando no desafio que ambos os discursos - o teológico e o poético - apresentam para a vida humana e de toda a criação nos tempos que correm.

Palavras-chave: teologia, sede, deserto, poesia, João Cabral de Melo Neto.

\section{The desert, the thirst, the life: dialogue between theology and João Cabral de Melo Neto's poetry}

\author{
Abstract \\ The desert is a very important and present metaphor in biblical spiritual life and \\ experience. The geographic hardness and the real thirst of those who cross desertic and \\ dry regions finds its correlation in the thirst human beings have in situations of injustice \\ and oppression. This article tries to gather and put into dialogue those elements when \\ it examines some biblical texts and João Cabral de Melo Neto's - Brazilian writer and \\ diplomatic who celebrates his ' $00^{\text {th }}$ anniversary - poetry. The dramatic poem "Morte \\ e Vida Severina" will be the writer's text analysed here. We analise the poem in itself, \\ commenting some of its verses which show a progression of Severino through the \\ spacial desert where he inhabits searching for life, which finally reveals itself in the \\ epiphany of new life of the other, who is born and invades despair and death. We will
}


try to conclude bringing some reflections which latin american theology has done in the last decades about the subjects of João Cabral poetry and landing in the challenge that both discourses - theological and poetic - resent to human life and all creation in contemporary times.

Keywords: theology, thrist, desert, poetry, João Cabral de Melo Neto

\section{El desierto, la sed, la vida: diálogo entre teología y poesía por João Cabral de Melo Neto}

\section{Resumen}

El desierto es una metáfora muy importante y presente en la vida y experiencia espiritual de la Biblia. La dureza geográfica y la sed real de quienes atraviesan regiones desérticas y áridas encuentra su correlato en la sed que tiene el ser humano de vivir en situaciones de injusticia y opresión. Este artículo busca acercar y dialogar con estos elementos examinando algunos textos bíblicos y la poesía de João Cabral de Melo Neto, escritor y diplomático brasileño que este año celebra su centenario. El poema dramático Morte e Vida Severina será el texto del escritor que analizamos. Analizamos el poema en sí, comentando algunos de sus versos que muestran la progresión de Severino por el desierto espacial que habita en busca de vida, que finalmente se revela en la epifanía de la nueva vida del otro, que nace e invade la desesperanza y la muerte. Intentaremos concluir trayendo algunas reflexiones que la teología latinoamericana ha hecho en las últimas décadas sobre los temas trabajados por la poesía de João Cabral y aterrizando en el desafío que ambos discursos, teológicos y poéticos, presentan para la vida humana y para toda la creación estos días.

Palabras clave: teología, sed, desierto, poesía, João Cabral de Melo Neto.

\section{Introdução}

O deserto é uma metáfora muito importante e presente na vida e na experiência espiritual do povo de Deus. Assim também o Espírito de Deus sempre foi uma metáfora fundamental para a vida que jorra abundantemente e não morre. A sede real dos que atravessam regiões desérticas e secas encontra seu correlato na sede que o ser humano tem de vida em situações de injustiça e opressão.

Este artigo procura reunir e fazer dialogar todos esses elementos ao examinar alguns textos bíblicos e a poesia de João Cabral de Melo Neto, escritor e diplomata brasileiro que este ano celebra centenário.

Em um primeiro momento procuraremos examinar alguns textos da Bíblia hebraica sobre o lugar do deserto na vida do povo de Israel ressaltando sua importância para a vida material de uma população nômade que buscava uma terra fértil e irrigada assim como o desejo espiritual que 
o povo experimenta ao estar longe da terra prometida que é a convivência com seu Deus. Em seguida refletiremos sobre um texto fundamental da Bíblia Cristã, o sermão da Montanha, examinando sobretudo uma das bemaventuranças, aquela que promete que a sede de fome e de justiça será saciada. Em seguida faremos a transição do texto bíblico para o poético com uma descrição do nordeste brasileiro - espaço onde João Cabral situa seu poema dramático, Morte e Vida Severina - como um espaço tradicionalmente atingido e ferido pela seca e pela miséria. Analisaremos então o poema em si mesmo, comentando alguns de seus versos que mostram uma progressão de Severino pelo deserto espacial que habita em busca de vida, que finalmente se revela na epifania da vida nova do outro, que nasce e invade a desesperança e a morte. Procuraremos concluir trazendo algumas reflexões que a teologia latino-americana tem feito nas últimas décadas sobre os temas trabalhados pela poesia de João Cabral e aterrissando no desafio que ambos os discursos o teológico e o poético - apresentam para a vida humana e de toda a criação nos tempos que correm.

\section{O deserto e a sede nas escrituras hebraicas}

Se algo é consenso na teologia bíblica, é que o deserto é algo fundamental na auto compreensão que o povo de Deus tem sobre sua identidade. A leitura de que foi liberto pela mão poderosa de Deus, Israel teve que vagar longamente pelo deserto antes de finalmente chegar à terra da promessa. Nessa travessia os hebreus libertos viveram a dúvida, a vulnerabilidade e a insegurança que os fez muitas vezes duvidar e desejar mesmo voltar à escravidão do Egito, onde pelo menos havia comida. ${ }^{1}$

Estar no deserto nessa circunstância e momento é sentido como estar na morte ou perto dela, longe da terra dos vivos, que depois se tornará a Terra Santa. Assim se entende a pergunta que faz o povo indignado a Moises em Ex 14,11-12:

Não havia sepulcros no Egito, para nos tirar de lá, para que morramos neste

... até os próprios israelitas tornaram a queixar-se, e diziam: "Ah, se tivéssemos carne para comer! Nós nos lembramos dos peixes que comíamos de graça no Egito, e também dos pepinos, das melancias, dos alhos porós, das cebolas e dos alhos. Mas agora perdemos o apetite; nunca vemos nada, a não ser este maná! "Números 11:4-6; E os filhos de Israel disseram-lhes: Quem dera tivéssemos morrido por mão do Senhor na terra do Egito, quando estávamos sentados junto às panelas de carne, quando comíamos pão até fartar! Porque nos tendes trazido a este deserto, para matardes de fome a toda esta multidão." (Ex. 16,3) 
deserto? Por que nos fizeste isto, fazendo-nos sair do Egito? Não é esta a palavra que te falamos no Egito, dizendo: Deixa-nos, que sirvamos aos egípcios? Pois que melhor nos fora servir aos egípcios, do que morrermos no deserto. ${ }^{2}$

O beijo quente da fome e da sede fez com que para os israelitas, desde muito cedo, o deserto seja concebido como um lugar difícil e perigoso, vazio de pessoas, cheio de solidão. Lugar de animais perigosos e demônios que tentam. O deserto na Bíblia é, pois, muitas vezes sinônimo de desolação, e esta é fruto da ameaça da morte e da destruição, sentida como abandono ou como castigo de Deus. Sobretudo na Bíblia Hebraica o deserto é então o contrário do paraíso, ou seja, representa o caos originário, no seio do qual nada se distingue ou se pode perceber com clareza. ${ }^{3}$

O deserto é igualmente o lugar da errância, do nomadismo. Enquanto o povo andava pelo deserto, sem vislumbrar a terra da promessa, sofria com o desejo da estabilidade e da sedentarização que não vinha. E assim como o ser humano rejeita e detesta o caos, que o atira na anomia e na anarquia para as quais não foi feito, assim igualmente odeia e rejeita a errância e o vagar sem descanso e sem lugar para repousar a cabeça, sem uma terra para pisar e sentir que é sua. ${ }^{4}$

Chama a atenção nossa e também de alguns comentadores que Deus pareça demonstrar um desejo de que o povo viva no estado nomádico. E se esta afirmação parece absurda, pode-se deixar de recordar que foram essas as condições para as quais chamou Abraão? ${ }^{5} \mathrm{E}$ ainda parece que é nas particularidades dessa vida nômade que Deus estabelece e configura suas relações de aliança muito especiais com o povo eleito do seu coração. ${ }^{6}$ Isso mostra que o deserto, juntamente com o medo e a rejeição que provoca,

2 Cf. o comentário de N. Wyatt, Sea and desert: symbolic geography in West Semitic religious thought, Ugarit-Forschungen 19 (1987) 376

3 Sobre isso: Aelred Cody, What the desert meant in Ancient Israel, Studia Missionalia 28 (1970), p 29

4 Até hoje isso pode ser observado na luta de tantos povos e tantos grupos humanos por uma terra, um lugar para cultivar, um teto para cobrir-lhe a cabeça. O ser humano não é nem pode ser a-tópico, mas pelo contrário, necessita de um espaço no mundo a fim de sentir-se vivo, protegido, abrigado.

5 Cf. Gen 12,1 ss. Veja-se o comentário de Malcolm Hunter, The Elusive Nomad. God and the Nomads: Highlighting the Biblical Narrative, International Journal of Frontier Missiology, 31: 3 (Fall 2014) 123

6 Ibid. 
aparece igualmente no texto bíblico como lugar de encontro com Deus, longe de todas as tentações idolátricas e desvios de conduta nas quais o povo possa cair.

No entanto, percebe-se que a concepção do deserto refletida nos textos bíblicos vetero-testamentários, - apesar de não ser unívoca - em sua maioria, dá testemunho de uma aversão e um medo. Inclusive as figuras humanas mais associadas com o deserto (Ismael, o filho bastardo de Abraão e Esaú, que se opõe a Jacó) não são positivamente paradigmáticas. ${ }^{7}$

O deserto na verdade tem duas referências primárias: uma espaçogeográfica e a outra temporal-histórica. Para a primeira o contraste entre as regiões cultivadas agricolamente com o deserto selvagem habitado por homens e animais selvagens, a imagem é basicamente negativa. Há, no entanto, juntamente com estas, algumas imagens positivas associadas ao deserto (o pastor, a tenda).

Para a segunda a distinção é entre reminiscência histórica e a experiência da midbar. ${ }^{8}$ Aparece a noção do período selvagem e desértico como castigo, metáfora para o conceito de povo pária (judeu) que emergiu no exílio. ${ }^{9}$

Portanto, não é só nos primórdios de sua história que o povo experimenta essa angústia de estar no lugar da errância, da desolação e da sede, longe das fontes da vida. A experiência duríssima do exílio na Babilônia buscou no primeiro êxodo, passagem voluntária e organizada da escravidão para a libertação, a referência para entender o segundo êxodo forçado e violento do cativeiro da Babilônia. O Egito era terra de morte e a Babilônia também o é. ${ }^{10}$ Com o agravante que o exilio na Babilônia aconteceu quando já havia a experiência da terra onde havia sido construído o templo. Por isso o deserto da Babilônia tem características de verdadeira e intransponível aporia, uma vez que a sede do povo já não é mais apenas da água que jorra das fontes e dessedenta o corpo, mas também e mesmo principalmente da água viva da presença do Senhor que está no templo e se comunica com o

\footnotetext{
7 Cf. N. Wyatt, ibid, 386 citando S. TALMON, The "desert motif"in the Bible and in Qumran literatura, 31-63 in A. ALTMANN (ed) Biblical motifs (Cambridge, Mass,s 1966). Cf. sobre Israel, a interessante reflexão de Elsa Tamez sobre Aga, mãe de Ismael: The woman who complicated the history of salvation, Cross Currents (summer 1986) 129-139.

8 Midbar em hebraico significa segundo os autores citados supra, na nota 7 , wilderness, ou seja, deserto, area desolada.

9 N. Wyatt, art. Cit.

10 Cf. N. Wyatt, art. Cit., 376
} 
povo fazendo sentir seu amor que desaltera e dá sentido à vida. E o povo se pergunta então, angustiado e perplexo:

Às margens dos rios de Babilônia, nos assentávamos chorando, lembrando-nos de Sião. Nos salgueiros daquela terra, pendurávamos, então, as nossas harpas, porque aqueles que nos tinham deportado pediam-nos um cântico. Nossos opressores exigiam de nós um hino de alegria: Cantai-nos um dos cânticos de Sião. Como poderíamos nós cantar um cântico ao Senhor em terra estranha? (Salmo 137:1-4)

Por isso a questão do deserto no exílio da Babilônia se complexifica. Já não é mais apenas a experiência da desnutrição e da desidratação física e biológica, mas a sensação de estar longe, separado do Senhor. E se o povo expressa essa nostalgia e essa dolência referindo-se à cidade santa de Jerusalém ${ }^{11}$ que é de por si, um lugar geográfico, refere-se sem dúvida mais ainda ao lugar simbólico e religioso, ou seja, ao Templo que guarda em si o santo dos santos e onde se encontra a presença de Deus.

Isaías, em seu capítulo 21, 1-10 sugere que o avanço do exército invasor transforma o Paraiso (ou seja, a Terra Santa) em um deserto. Quer dizer, desfaz a criação. A diferença entre o Paraíso e o deserto é revertida. Em lugar do caos originário se transformar em cosmos organizado pelo Criador, o cosmos reverte-se em caos. Mas a visão do profeta recebe uma resposta do Senhor: "Caiu, caiu Babilônia; e todas as imagens esculpidas de seus deuses são despedaçadas até o chão" (Is 21,9). A esperança do povo deve ser mantida e para isso há que partir da desolação desértica do exílio para reconciliar o povo com a realidade que vive e animá-lo a esperar no Senhor para viver essa situação e superá-la.

$\mathrm{Na}$ verdade, estamos aqui diante de uma geografia real transferida para uma geografia simbólica. ${ }^{12} \mathrm{O}$ uso do símbolo é essencial em teologia, como afirma o grande teólogo Karl Rahner: "todas as coisas são por sua

11 Cf. a continuação do Sl 137, que comentamos acima: Se eu me esquecer de ti, ó Jerusalém, que minha mão direita se paralise! Que minha língua se me apegue ao paladar, se eu não me lembrar de ti, se não puser Jerusalém acima de todas as minhas alegrias. Contra os filhos de Edom, lembrai-vos, Senhor, do dia da queda de Jerusalém, quando eles gritavam: Arrasai-a, arrasai-a até os seus alicerces! (Salmos 137:5-7)

12 Ver sobre isso José Elias Pinheiro Neto, Geografia e Literatura: a paisagem geográfica e ficcional em Morte e Vida Severina de João Cabral de Melo Neto, Boletim Campineiro de Geografia. v. 2, n. 2, 2012 
mesma natureza, simbólicas." ${ }^{13}$ Dentro desta chave simbólica, há portanto dois modelos para a compreensão do espaço: um vertical, urânico e tripartite que vê os deuses acima, o ser humano na terra e os mortos abaixo da terra.. O segundo horizontal, telúrico, que vê a realidade como o ponto central e diminui na medida em que se afasta do centro até ficar como um deserto amorfo e sem contornos, cercado por um oceano cósmico (mar ou rio ou abismo) para além do qual está a morte e o caos. ${ }^{14}$

Esses modelos se aplicam ao ser humano em si mesmo. A realidade não está em um extremo ou em outro, mas numa dimensão que os reconcilia e transcende. A periferia é uma extensão do centro e reforça sua vitalidade. É assim que os judeus na situação "desértica" do exílio iniciam um processo de quebra de uma concepção puramente "natural" da vida e da fé entrando no mundo metafórico e simbólico da estrutura relacional com seu Deus. A função primeira dos símbolos é, portanto, permitir aos seres humanos, em linguagem humana, nomear e a partir daí facilitar a revelação daquilo que é transcendente e ultrapassa o alcance da forma e da formulação humanas. ${ }^{15}$

O verdadeiro deserto é estar longe de Deus e a verdadeira sede é aquela situação na qual não se sente nem se saboreia sua presença. Deus é vida e fecundidade. E os profetas do exilio (o Deutero Isaias, Ezequiel) vão consolar o povo, levando-o a perceber que o mesmo Deus que lhes deu uma terra foi o que deu à humanidade um mundo. Ele é o Criador de tudo que existe e, portanto, está presente tanto em Canãa, no templo de Jerusalém, como na Babilônia. É possível, portanto, cantar ao Senhor tanto lá como cá. O deserto geográfico e existencial não podem ser empecilhos definitivos para a vida em plenitude que a presença de Deus gera e concede ao povo.

A sede de vida que o povo sente e que é provocada pelos desertos tanto geográficos como interiores será igualmente abordada na Bíblica Cristã, desta vez a partir das palavras e da gesta de Jesus de Nazaré, reconhecido e proclamado pela primeira comunidade o Cristo de Deus. Os ensinamentos de

13 Karl Rahner, Theological Investigations: More Recent Writings, vol. 4, Darton, Longman \& Todd, 1966 244-245.

14 Cf. Wyatt, art cit., 389 acrescenta que pode haver aí uma possível interpretação de uma nostalgia da condição pré-cósmica. No caos primigênio não se distinguem as coisas e as pessoas. A vida é separação e sofrimento. Há que suportar as diferenças, o que nem sempre é fácil. Então o rito e o culto são a salvação, estruturando o espaço e o tempo. Mas também correndo a tentação de abolir o espaço e o tempo.

15 Cf. Sherri Brown, Cherri, Water imagery and the power and presence of God in the Gospel of John, Theology today 72, 3 (2015), 291. 
Jesus situarão a sede humana em termos não apenas em relação à água sem a qual a vida morre, mas também em relação à justiça que desaltera a aridez da vida daqueles que vivem oprimidos sob algum jugo, seja o da pobreza, da violência ou de todas as opressões.

\section{Sede de justiça: a que será saciada}

O sermão da montanha é conhecido universalmente por ser a Carta Magna do Reino de Deus. Falando sempre às multidões e seguido por elas onde quer que fosse, nesta pericope os evangelistas sinóticos - Mateus e Lucas - mostram Jesus ensinando aos discípulos o segredo do seu seguimento que é a única coisa que os pode fazer felizes - bem-aventurados. Carlos Mesters - o grande biblista brasileiro, criador dos círculos bíblicos, - explica:

O Sermão da Montanha abre-se com oito bem-aventuranças. Elas são o portão de entrada deste e dos textos que seguem. Declaram felizes os pobres caracterizados de oito maneiras, pois neles o Reino de Deus já se faz presente como dom e graça de Deus no meio de nós e apesar de nós. Deste modo, as bem-aventuranças nos informam onde devemos olhar para descobrir os sinais da presença deste Reino no mundo em que vivemos. ${ }^{16}$

A palavra bem-aventurado tal como aparece em grego no sermão da montanha, em Mt 5 e Lc 6 (makarioi) é um adjetivo que significa "feliz". Porém, bem-aventurança é algo infinitamente maior e melhor do que o mero significado que damos à palavra "felicidade". A palavra grega é antiga, já usada por Homero e Píndaro, sendo posta na boca dos deuses gregos e também dos humanos, ainda que mais no sentido de prosperidade. Também foi entendida com respeito aos justos que morrem no Senhor. E já na Bíblia hebraica tinha o sentido de uma qualidade moral, podendo ser aproximada da sabedoria e da condição do sábio. Jesus toma essa palavra e a insere em seu contexto. Por sua aproximação, no Sermão da Montanha, com as condições adversas e miseráveis nas quais vivem aqueles que chama felizes, bem-aventurados, não apenas transforma seu conteúdo como ainda enobrece a palavra que emprega. Aqui comentamos a perícope a fim de compreender melhor o sentido que a Bíblia cristã dá à palavra felicidade, tão banalizada hoje em seu uso. ${ }^{17}$

\footnotetext{
16 Carlos Mesters, Ouvi o clamor do meu povo, Estudos Bíblicos de Mt 5 - 9 , in Estudos Bíblicos 26, p. 62.

17 http://www.biblestudytools.com/commentaries/robertsons-word-pictures/matthew/ matthew-5-3.html 10/2/2016
} 
Mateus diz que ele viu as multidões desde o alto da montanha. Mas seus discípulos vieram até ele, ou seja, sentaram-se mais perto de onde ele estava. É o que faz supor, com muitos exegetas, que o sermão da montanha é algo proposto a todos, mas muito especialmente aos discípulos. ${ }^{18} \mathrm{O}$ mestre trata de propor-lhes uma regra de vida, diferente da dos escribas e dos fariseus. Só esta poderá faze-los felizes.

Ao pronunciar estes ensinamentos, Jesus reflete uma sabedoria diferente, que o faz parecer mais um sábio, menos dependente das escrituras judaicas e da tradição mosaica, mesmo em Mateus. ${ }^{19}$ Trata-se de uma sabedoria, segundo Meier, que beira o gênero apocalíptico, acabando por dizer mais ou menos o seguinte: "Felizes os infelizes, porque Deus os fará felizes no último dia". ${ }^{20}$

É neste contexto que fala da sede (na verdade fome e sede) de justiça prometendo saciedade aos que a experimentarem. Aqueles que sentirem um intenso desejo pela justiça a obterão. Trata-se de uma promessa que não se encontra em outras religiões. No entanto, aqui é clara e bem definida. ${ }^{21}$ E como sempre em Mateus - mais do que em Lucas - está marcada pela tensão entre o corpóreo e o spiritual, entre uma felicidade oferecida aqui e agora, mas projetada para o final dos tempos. No entanto, a bemaventurança consiste em desejá-la ardentemente, esperá-la e lutar por ela. ${ }^{22}$ Segundo alguns ilustres exegetas, as bem-aventuranças de Jesus claramente são escatológicas no seu núcleo mais central. "A felicidade humana não é mais definida por uma sabedoria limitada a um futuro humano, mas pela promessa de Deus focalizada no futuro de Deus". ${ }^{23}$

Alguns teólogos bíblicos comentam o fato de que algumas situações mencionadas por Jesus no Sermão da Montanha são imediatamente identificáveis com a materialidade (fome, sede, pobreza, pranto, perseguição) mas igualmente convidam a uma transposição espiritual, deixando perceber o

\footnotetext{
18 Cf. Jacques Dupont, Les Béatitudes, Paris, J. Gabalda, 1973

19 Cf John P. Meier, Matthew 5: 3-12, Interpretation, 44 no 3 Jul 1990, 281-282

20 ibid 282.

21 http://www.biblestudytools.com/commentaries/jamieson-fausset-brown/matthew/ matthew-5.html 10/2/2016.

22 Referimo-nos aqui à diferença de empostação entre os dois evangelistas. Enquanto Mateus fala de "pobres em espírito", Lucas fala de "pobres"sem adjetivos, etc. Isso explica por que na teologia latino-americana, o texto de Lucas é muito mais utilizado. Sobre isso ver também o comentário de Jacques Dupont em sua clássica obra Les Béatitudes, a nosso ver ainda não superada em rigor e profundidade

23 John P. Meier, art. cit., 283
} 
cunho metafórico e simbólico com o qual refletem e escrevem os evangelistas: pobreza de espírito, fome e sede de justiça, perseguição por causa da justiça). ${ }^{24}$

No entanto, em Mateus, a bem-aventurança dos que têm fome e sede de justiça e que segundo Jesus serão saciados tem um tom mais ativo do que normalmente se vê em outras da lista. ${ }^{25}$ Assim aqueles que são declarados bem-aventurados são os que mostram misericórdia para outros. Portanto, esses têm fome e sede de justiça, sofrem perseguição por causa da justiça porque realizam a vontade de Deus. Em suma, os bem-aventurados o são, mesmo na tribulação e na perseguição porque agem contra as causas dessa tribulação, não só para si mesmos, mas para outros, para todos. ${ }^{26}$

A tensão entre a dimensão material e a espiritual continua em fecunda tensão dialética aqui como antes. A promessa de Deus pronunciada sobre a sede humana de justiça dizendo que esta será saciada configura a vida presente daquele ou daquela que escuta e crê na mensagem de Jesus no sermão da montanha e por isso tem sua vida plenificada para refletir a ação salvífica de Deus em sua própria ação. $\mathrm{Na}$ verdade, o que a bem-aventurança da sede de justiça diz é que os discípulos de Jesus se recusam a aceitar este mundo tal como ele é como meta absoluta de sua existência e por isso têm a coragem de começar a transformá-lo, mostrando a misericórdia de Deus, realizando a paz e a justiça de Deus para todos. ${ }^{27}$

O ideal de perfeição com que Jesus encerra o seu discurso, exortando os discípulos a serem imitadores de Deus na verdade remete a sua pessoa e conduz ao seguimento da mesma. E isso está longe de ser uma alienação ou uma fuga do mundo. Pelo contrário, os evangelistas reafirmam que o único caminho para a verdadeira felicidade é o seguimento de Jesus, porque ele foi o único homem plenamente feliz neste mundo, uma vez que a única coisa que aplacava sua sede era fazer total e completamente a vontade de seu Deus e Pai. E isso em meio a qualquer situação, negativa ou positiva.

Assim, mostrando quem é bem-aventurado, Jesus mostra a si próprio. E como sempre acontece quando lemos o Evangelho, em seu caso, meio e

24 Cf. por exemplo, Antonio Sicari, The hunger and thrist of Christ, Communio 18 (1991) 590-591

25 John P. Meier comenta que isso se deveria a que as bem-aventuranças em Mateus provem de uma lista M, que é mais ativa do que a tradicional lista Q. Cf. art. cit 284. Cf. igualmente sobre essa dimensão ativa das bem-aventuranças Pinchas Lapide, The sermon of the mount: utopia or program for action? NY, Orbis, 1986.

26 Ibid.

27 Cf. ibid 
mensagem se confundem e se superpõem. Ele é aquele que tem permanente sede de justiça porque tem permanente sede de realizar e fazer acontecer a vontade do Pai, que é a construção do seu Reino. Mas ao mesmo tempo ele é a fonte da água viva da qual todo sedento deve beber para poder desalterarse e viver em plenitude.

Ele é a encarnação da justiça de Deus e esta é sua missão messiânica. ${ }^{28}$ A mesma por sua vez remete à identidade e missão do rei em Israel. O povo custou a ter um rei, mas quando o teve, via nesse rei o intendente ideal da justiça divina. O rei deveria "defender a causa dos fracos e dos órfãos; manter os direitos dos pobres e oprimidos, resgatar os fracos e necessitados; libertá-los da mão dos malvados" (S1 82, 3-4). Esse é o padrão de justiça que tem que estar presente em qualquer legítima reivindicação de realeza.

E com sua vida e palavra, ele ensina e demonstra que a construção de estruturas sociopolíticas que promovam a visão profética de justiça e restaurem a shalom do povo de Deus fundamentalmente expressa a realeza divina. ${ }^{29}$ Portanto, a partir de sua pessoa e seu ministério a sede de Deus está para sempre confirmada como inseparável da sede de justiça. Em outras palavras, fé e justiça, mística e política não se separam na Sagrada Escritura, seja judaica, seja cristã. Trazer isso para a linha de frente do debate teológico contemporâneo foi a grande e profunda contribuição que a Teologia da Libertação deu ao conjunto de toda a teologia.

Com este pano de fundo nos dispomos então a analisar o famoso poema de João Cabral de Melo Neto. Ali estão presentes, parece-nos, os elementos principais dessa reflexão bíblica que até aqui apresentamos: o deserto como paisagem onde o personagem caminha no sertão e no agreste desejando chegar à agua do rio e do mar, o deserto interior da desolação, do sofrimento, da injustiça que o assola permanentemente, e a redenção que lhe é mostrada como única capaz de desalterar sua sede de vida vencedora da injustiça e da morte.

\section{O deserto da miséria e da fome: o nordeste brasileiro}

Embora seja um país tropical, o Brasil traz em sua superfície geográfica vários tipos de vegetação, incluindo a presença majoritária da floresta amazônica, considerada "pulmão do mundo". Em meio a essa pluralidade

\footnotetext{
28 Larry Chouinard, The kingdom of God and the pursuit of justiça in Matthew, Restoration Quarterly, 45 no 4 2003, p 229 com vasta bibliografia sobre o estado da arte desta questão.

29 Cf ibid e também Tom Wright, Jesus and the Victory of God, Minneapolis, Fortress, 1996
} 
climática e ambiental, a presença e a metáfora do deserto também estão aí presentes. Isto se dá notadamente na região nordeste, mais especificamente em parte dos estados de Alagoas, Bahia, Ceará, Paraíba, Pernambuco, Piauí, Rio Grande do Norte e Sergipe, atingindo ainda o Norte de Minas Gerais e o Vale do Jequitinhonha, também no estado de Minas Gerais.

Chama-se a este semiárido brasileiro de "sertão". O nome é derivado de outra palavra: "desertão", utilizada na época colonial para referir-se ao interior do país. Data essa denominação da época da colônia, quando os portugueses descreviam o semiárido como "desertão" devido às condições climáticas. O que restou da palavra, "sertão", foi fruto do uso do tempo e da repetição sobre a mesma. ${ }^{30}$

A aproximação do sertão com o deserto se deve a suas altas temperaturas e à seca que predomina em boa parte do ano, sendo em algumas ocasiões altamente prejudicial e letal à vida, matando gado e ocasionando fome, desnutrição e periculosidade de morte entre os habitantes. Em alguns anos a seca é pior do que em outros, como por exemplo em 1877 quando a mesma chegou a durar três anos, e mais recentemente no ano de 2012, quando foi forte e terrível. ${ }^{31}$

Ao contrário das demais regiões desérticas do mundo, o sertão não margeia zonas secas, mas sim zonas úmidas e isso é parte de sua atipicidade geográfica. A caatinga, por sua vez - vegetação que cresce no sertão - vem do tupi-guarani: caa (mata) + tinga (branca) e é o único bioma exclusivamente brasileiro, não sendo encontrado em nenhum outro lugar do planeta. Apresenta vegetação típica de regiões semiáridas, com perda de folhagem durante a seca. Durante as secas mais cruéis e prolongadas, os sertanejos tem usado a folhagem da caatinga inclusive para sua alimentação. ${ }^{32}$

A seca, presente desde o início da história do Brasil na região nordeste tem originado vários outros fenômenos, como a miséria, a fome e os fluxos

30 Há também, estudiosos que afirmam tratar-se de uma corruptela da palavra sertã (frigideira) pelo fato de ser uma região onde se registram altas temperaturas." Cf. sobre isso de Marcos Paulo C. Pereira e Marcelo Lachat (org) Pelo Sertão, o Brasil , Macapá, UNIFAP, 2016.

31 Cf. sobre isso o artigo de Jose Nilson B. Campos e Ticiana Marinho de Carvalho Studart, Secas no nordeste do Brasil: origens, causas e solucoes, em Fourth Inter-American Dialogue on Water Management, 201, Foz do Iguaçu, Anais do IV Diálogo Interamericano de Porto Alegre: Associação Brasileira de Recursos Hidricos, 2001, v. 01

32 http://www.invivo.fiocruz.br/cgi/cgilua.exe/sys/start.htm?infoid=962\&sid=2 acessado em 24 de outubro de 2020. Muitas vezes durante as secas mais fortes, tudo que o sertanejo encontra para comer é essa vegetação, fazendo com que ele se alimente exclusivamente da mesma. 
migratórios. ${ }^{33}$ Tudo isso obstaculizou um maior desenvolvimento da região e um maior crescimento populacional. As reservas hídricas se resumiam, até pouco tempo atrás, a pequenos açudes e águas de presença instável dos aquíferos fluviais. Bastava uma seca mais severa que a população e seriamente atingida, assim como o gado, gerando uma enorme vulnerabilidade na região. Hoje há o projeto da transposição do rio São Francisco para canalizar as águas fluviais para as regiões atingidas pela seca. Mas o problema está longe de ser resolvido. ${ }^{34}$

Ha vários conceitos de secas, assim como várias reflexões acadêmicas sobre suas causas. ${ }^{35}$ Além de ser um problema climático, trata-se de uma situação que gera dificuldades sociais para os habitantes da região, propiciando obstáculos à agricultura e à pecuária, fome, miséria, falta de água inclusive para beber. As pessoas são obrigadas a caminhar durante horas sob sol e calor para buscar água em algum poço, sendo esta agua muitas vezes contaminada e não própria para beber. Além disso está o desemprego, o êxodo rural em direção às cidades que têm suas periferias inchadas e superpovoadas em condições igualmente de extrema pobreza e em áreas de risco. As ações públicas para remediar os males da seca até o momento têm se revelado insatisfatórias. Existe até mesmo a chamada "indústria da seca", que consiste - entre outras coisas - na exploração da mão de obra quase escrava que permanece fixa na região, aprofundando o problema em lugar de saná-lo. ${ }^{36}$ Recentemente, a transposição de rios no Brasil tem ocasionado a penalização de populações ribeirinhas que se veem de repente privadas de seu meio de vida e devendo extrair o sustento de um solo não mais fértil,

33 Ibid.

34 Cf. Edmilson Soares, Seca no Nordeste e a transposição do rio São Francisco, Geografias, Belo Horizonte, 01 de Julho - 31 de Dezembro de 2013. Vol. 9, n 2, 201375.

35 O texto que citamos, Secas no Nordeste: origens, causas e soluções, de José Nilson Campos e Ticiana Marinho de Carvalho Studart in http://www.repositorio.ufc.br/handle/riufc/9326, acessado em 20 de outubro de 2020, identifica quatro definições de seca: a climatológica; a edáfica; a social e a hidrológica. Aqui nos interessa mais diretamente a seca social, buscando sua interpretação teológica.

36 Cf. https://pt.wikipedia.org/wiki/Seca_no_Brasil\#Ind.C3.BAstria_das_secas acessado em 7 de marco de 2016; "Indústria da seca é um termo utilizado no Brasil para designar a estratégia de certos segmentos das classes dominantes que se beneficiam indevidamente de subsídios e vantagens oferecidos pelo governo a partir do discurso político da seca. O termo começou a ser usado na década de 60 por Antonio Callado, quando escreveu no jornal Correio da Manha "Os industriais da sếca e os "Galileus" de Pernambuco: aspectos da luta pela reforma agrária no Brasil” que denunciava os problemas da região do semi-árido brasileiro. 
mas árido e estéril. É a outra face de um projeto aparentemente positivo, como a transposição do São Francisco. Mas a corrupção e a ação humana desviada fazem com que se torne algo ameaçador e negativo.

Lugar tomado pela presença constante de pobreza e miséria, de morte e infelicidade para tantos cidadãos brasileiros, o "desertão" nordestino e seus problemas constantes de seca chamou muito a atenção da Igreja brasileira, concretamente dos bispos do Brasil, cuja conferência episcopal produziu documentos que denunciavam a indústria da seca e chamavam a atenção das autoridades para as consequências da mesma na vida e na morte dos habitantes da região. ${ }^{37}$

O fenômeno da seca no "desertão" brasileiro inspirou igualmente poetas, músicos, escritores. As músicas entram no ouvido do povo e são cantadas inclusive nas celebrações litúrgicas para expressar diante de Deus o tormento que a seca traz. Como por exemplo na canção "Seca do Nordeste", de Fagner: $\hat{O}$ sol! sol escaldante/Terra poeirenta/Dias e dias, meses e $m$ e s e s sem chover/E o pobre lavrador com a ferramenta rude/ Bate forte no solo duro. Ou ainda a canção "Vozes da seca", onde o grande compositor pernambucano Luiz Gonzaga questiona os políticos a respeito da condição do nordestino, que é um homem cheio de dignidade, mas se encontra humilhado por ter que receber esmolas por não ter condição de trabalhar: Seu doutô os nordestino têm muita gratidão/Pelo auxílio dos sulista nessa seca do sertão/Mas doutô uma esmola a um homem qui é são/ Ou lhe mata de vergonha ou vicia o cidadão.

Em suma, o problema da seca e dos mais graves que enfrenta o Brasil e uma das maiores fontes da injustiça social e da pobreza extrema que ainda vigora em algumas regiões do pais. Órgãos públicos têm procurado soluções para o problema, mas isso não se tem mostrado suficiente. Talvez porque a corrupção impede os recursos de chegarem aos destinatários e engorda os bolsos dos políticos e intermediários. Com o agravamento do desmatamento das regiões chuvosas, como a Amazônia, a seca só faz aumentar, transformando a vida dos pobres em um suplício renovado a cada ano.

Do coração dos cantores e compositores saem canções que expressam não apenas a dor da seca que mata toda a vida ao redor, mas igualmente a

37 Cf. por exemplo Carta dos bispos do Piaui sobre a seca, de dezembro de 2012 in http:// www.cnbb.org.br/index.php?option $=$ com_content\&view $=$ article\&id $=11158$ :carta-dosbispos-do-piaui-sobre-a-seca-1\&catid=156\&Itemid=212 acessado em 7 de marco de 2016. V. tb a nota de todos os bispos do Brasil reunidos em Aparecida em sua 51a assembleia, em 2013, conclamando a solidariedade com o povo nordestino castigado pela maior seca dos ultimos cinquenta anos. O titulo da nota e "Sede de agua e de justica" 
esperança de que volte o verde quando as chuvas caírem para que as plantações possam crescer, o gado viver, e a família se alimentar. Assim é que o mesmo Luis Gonzaga compôs essa que é um grande sucesso nacional hoje: Asa Branca: Quando o verde dos teus olhos/se espalhar na plantação/ eu lhe asseguro/ não chore não/ que eu voltarei viu/ meu coração. O sertanejo obrigado a migrar para o sul devido à seca que faz a "terra arder qual fogueira de São Joao", transformada em braseiro e fornalha, não deixando nem um pé de plantação, promete voltar quando o verde dos olhos da amada se espalharem pela plantação fazendo-a verde e apta para alimentar de novo seus habitantes.

O escritor João Cabral de Melo Neto ${ }^{38}$ nasceu na cidade do Recife, a 9 de janeiro de 1920 e faleceu no dia 9 de outubro de 1999, no Rio de Janeiro, aos 79 anos. Eleito membro da Academia Brasileira de Letras em 15 de agosto de 1968, tomou posse em 6 de maio de 1969. Foi recebido por José Américo. João Cabral foi um dos que recebeu inspiração do sertão, da seca e das condições de vida que eram as suas e de seus conterrâneos. Isso aparece presente em várias de suas obras, das quais a mais famosa é sem dúvida o poema épico e dramático "Morte e Vida Severina", de '1955. ${ }^{39}$

\section{Morte e Vida Severina: deserto e água na estrada da vida}

"Morte e Vida Severina"40 é um poema épico e dramático de João Cabral de Melo Neto e retrata não só a saga de uma pessoa - Severino como também a saga de todo um povo. Pode ser lido igualmente como metáfora da vida humana como um todo, às voltas com as dificuldades da pobreza e da injustiça. Assim como a vida do povo de Israel no deserto e no exilio e a dos contemporâneos de Jesus Cristo sob o jugo de uma potência estrangeira, o Império Romano, à espera da chegada do Libertador.

\footnotetext{
38 Cf. breve biografia do escritor publicada pela Academia Brasileira de Letras https://www. academia.org.br/academicos/joao-cabral-de-melo-neto/biografia\#: : :text $=\mathrm{Jo} \% \mathrm{C} 3 \% \mathrm{~A} 30 \% 20$ Cabral $\% 20$ de $\% 20$ Melo $\% 20$ Neto $\% 20$ nasceu $\% 20$ na $\% 20$ cidade $\% 20$ do $\% 20$ Recife,Foi $\% 20$ recebido\%20por\%20Jos\%C3\%A9\%20Am\%C3\%A9rico. Acessada em 20 de outubro de 2020.

39 Morte e Vida Severina notabilizou João Cabral inclusive fora do Brasil. A tradução do poema em inglês foi feita por Elizabeth Bishop, famosa escritora estadunidense, ganhadora do Premio Pulitzer. Cf Note from Elizabeth Bishop, "The Death and Life of a Severino", in Poetry, Vol. 103, No. 1/2, Work in Progress: Long Poems, Sequences (Oct. - Nov., 1963), pp. 10-18.

40 Foi utilizada a seguinte edição em e-pub: MELO NETO, João Cabral de. Morte e Vida Severina e outros poemas. Rio de Janeiro: Alfaguara/Objetiva: Rio de Janeiro, 2007.
} 
Ao mesmo tempo em que traz no título o nome do personagem central, - Severino, - nome muito comum no Nordeste -, o poema deixa claro que se trata de mais do que um nome próprio de um indivíduo. Severino, figura simbólica e emblemática é um retirante. Ou seja, um migrante, um nômade, um caminhante. Vai em busca de vida. Tem sede dela, sede de trabalho justo, que remunere justamente e lhe de plenitude de vida. Sede de sair da vida Severina para viver dignamente. Sede de viver uma vida que não seja apenas morte adiada. ${ }^{41}$

O personagem explica já no início do texto as circunstâncias que cercam seu nome.

O meu nome e Severino,

Não tenho outro de pia.

Como há muitos Severinos,

Que é santo de romaria,

Deram então de me chamar

Severino de Maria;

mas como há muitos Severinos

com mães chamadas Maria,

fiquei sendo o da Maria

do finado Zacarias.

Mas isso ainda diz pouco:

Ha muitos na freguesia,

Por causa de um coronel

Que se chamou Zacarias

E que foi o mais antigo

Senhor desta sesmaria.

Logo porém, na fala de Severino de Maria do Zacarias la da serra da Costela limites da Paraíba aparece a verdadeira intenção do poeta. Para ele na verdade Severino não é um indivíduo determinado, mas o epônimo, a personalidade corporativa dos retirantes sertanejos nordestinos. Severina na verdade é a vida que levam. Vida dura e castigada, pela seca, pela opressão, pelo latifúndio, sempre ameaçada pela morte. Assim descreve Severino retirante, narrador do poeta, sua vida e a morte que um dia será a sua.

41 Assim como a poesia de João Cabral, a Teologia da Libertação na América Latina também denunciou a morte prematura que vinha a ser a dos pobres. E a razão é que a pobreza lhes rouba a vida, fazendo com que a morte a trague prematura e cruelmente. A TdL denunciou isso como contrário à vontade de Deus. Cf. entre outras obras, de Gustavo Gutiérrez, Teologia da Libertação, Petrópolis, Vozes, 1971; Jon Sobrino, Jesus na América Latina. Ensaio a partir das vítimas, SP, Loyola, 2000. 
Somos muitos Severinos

Iguais em tudo na vida

$\mathrm{Na}$ mesma cabeça grande

Que a custo e que se equilibra,

No mesmo ventre crescido

Sobre as mesmas pernas finas

E iguais também porque o sangue

Que usamos tem pouca tinta.

E se somos Severinos

Iguais em tudo na vida,

Morremos de morte igual,

Mesma morte Severina:

Que é a morte de que se morre

De velhice antes dos trinta

De emboscada antes dos vinte

De fome um pouco por dia

(de fraqueza e de doença

e que a morte Severina

ataca em qualquer idade,

até gente não nascida) ${ }^{42}$

Severino emigra e justifica sua apresentação:

Mas para que me conheçam

Melhor Vossas Senhorias

E melhor possam seguir

A história de minha vida

Passo a ser o Severino

Que em vossa presença emigra.

Severino migra porque esse é o seu destino, enquanto sertanejo e nordestino. Retirante, vive retirando-se de um lugar e rumando para outro, em busca de vida, de trabalho, de recursos de sobrevivência. Neste sentido é paradigmático não apenas do nordestino, mas do ser humano que e sempre um caminhante, um peregrino nesta vida guiado pela sede de viver mais plenamente. Seu destino é o mesmo do povo de Deus no deserto e de todos os migrantes que hoje cruzam o planeta em busca de melhores condições de trabalho e de vida.

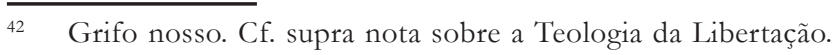


Em seu caminho Severino vai rezando o rosário, cujas contas ele compara às vilas e cidadezinhas pelas quais vai passando. E no seu caminho só encontra mortos e funerais. Primeiramente um que morreu de bala porque quiseram lhe retirar a terra que possuía, depois um finado sendo velado em casa. O catolicismo popular cerca essas mortes com rezas, benditos, cânticos e rituais.

O retirante se impressiona por só encontrar morte em seu caminho.

Desde que estou retirando

Só a morte vejo ativa,

Só a morte deparei

$\mathrm{E}$ as vezes até festiva

Só a morte tem encontrado

Quem pensava encontrar vida

E o pouco que não foi morte

Foi de vida Severina

(aquela vida que é menos

vivida que defendida,

e é ainda mais Severina

para o homem que retira)

Ao interrogar uma mulher que vê a janela e perguntar-lhe se há trabalho para ele, ouve a resposta que ali a única profissão que prospera e a da morte. Ela mesma trabalha nisso e não dá conta de tanto trabalho. Oferecelhe uma parceria, mas pergunta se ele sabe benditos rezar, cantar incelenças, defuntos encomendar, cantar ladainhas e mortos enterrar. Mas o retirante busca vida e não morte. Não aceita a oferta da mulher. Continua seu caminho e chega ao litoral, onde a terra lhe parece prospera e onde com certeza não encontrara mais tanto a morte, mas a vida.

Para sua surpresa, depara com o enterro de um trabalhador do qual os companheiros expõem a causa da morte. Sua morte é fruto da injustiça, da acumulação do capital, do impiedoso latifúndio e da ganância dos proprietários de terra que exploraram sua força de trabalho e nada lhe deram. Vai ser depositado na terra, a terra que bebeu seu suor, sua juventude, sua força de marido;

Este chão te é bem conhecido

Bebeu teu suor vendido...

Este chão te é bem conhecido 
Bebeu tua força de marido...

a terra onde tantas vezes semeou, mas onde agora ele mesmo é a semente Não levas semente na mão

És agora o próprio grão

Já não tens força na mão

Deixa-te semear no lerão

A terra que queria ver dividida, mas que o latifúndio tomou para si, dando-lhe em troca apenas a cova onde será enterrado

Esta terra em que estás com palmos medido

É a cota menor que tiraste em vida.

É de bom tamanho

Nem largo nem fundo,

É a parte que te cabe

Neste latifúndio

Não é cova grande,

É cova medida

É a terra que querias ver dividida.

O chão aberto para receber o cadáver do nordestino que trabalhou em condições terríveis e exploradoras é a única cama e coberta que ele jamais recebeu ou receberá. Este chão o abraça como mulher apaixonada.

E agora se abre o chão e te abriga

Lençol que não tiveste em vida

Se abre o chão e te fecha

Dando-te agora cama e coberta.

Se abre o chão e te envolve,

Como mulher com quem se dorme.

O abraço mortal da caatinga, da terra desértica fecha-se sobre o defunto. A terra que não lhe deu nada em vida lhe dá pelo menos sepultura. A terra da qual seu braço tirou impossíveis frutos agora é sua última morada, sem que nem ele nem os seus conheçam qualquer amparo. A morte é a única que o recebe em seus braços, nessa terra de outros que ele trabalhou e plantou, mas que jamais foi sua.

Severino contemplando toda essa cultura de morte reflete consigo e recita. Não buscava muita coisa, não ambicionava ser rico. Queria ver apenas se escapava de morrer de velhice antes de inteirar trinta anos. Queria viver, viver mais, viver melhor. Mas por onde passou, pelo Agreste pernambucano, pela caatinga nordestina, pela zona da mata, só encontrou a monotonia de sempre: 
a morte em seu trabalho predatório de ceifar vidas através da pobreza, da injustiça, da exploração.

Severino se dirige então ao Recife, capital do estado de Pernambuco, apressando o fim de seu rosário, de sua reza, de sua ladainha que implora por vida e só encontra morte.

Sim, o melhor é apressar

O fim desta ladainha

O fim do rosário de nomes

Que a linha do rio enfia;

E chegar logo ao Recife,

Derradeira Ave Maria

Do rosário, derradeira

Invocação da ladainha

Chegado ao Recife, cidade grande, o retirante senta-se para descansar ao pé de um muro alto e ouve por acaso a conversa de dois coveiros. São profissionais de enterrar mortos e comentam seu ofício comparando os serviços que prestam aos ricos dos bairros mais poderosos da cidade com a proliferação de enterros pobres que devem realizar de maneira que quase já não há mais lugar disponível para enterrar tanta gente. Severino então constata que a situação da cidade grande não e muito diferente do que a do campo. Aqui também a vida é um deserto e a morte espreita por todos os lados, sobretudo aos pobres. Aqui também a sede de vida abrasa e não sacia.

Aos ouvidos aterrados do retirante, os dois coveiros comentam levianamente os enterros desses que são

Gente sem instituto

Gente de braços devolutos;

São os que jamais usam luto

E se enterram sem salvo-conduto.

É a gente dos enterros gratuitos e dos defuntos ininterruptos

É a gente retirante

Que vem do sertão de longe...

E que então ao chegar

Não tem mais o que esperar...

Não tem onde trabalhar

E muito menos onde morar

E da maneira em que está

Não vão ter onde se enterrar 
Os pobres incomodam aqueles que tem que viver de enterra-los. Enterrar os pobres não é lucrativo, não dá gorjeta, não vale a pena. Os coveiros continuam em sua lógica mortífera, comentando que esses retirantes poderiam encontrar outra solução para suas mortes, a fim de não incomodar mais aqueles que trabalham e ganham a vida honestamente.

$\mathrm{Na}$ verdade, seria mais rápido

E também muito mais barato

Que os sacudissem de qualquer ponte

Dentro do rio e da morte.

O rio daria a mortalha e até um macio caixão de agua...

E não precisava dinheiro,

E não precisava coveiro,

E não precisava oração

E não precisava inscrição...

Mas o que se vê não é isso...

Morre gente que nem vivia.

E esse povo de lá de riba

De Pernambuco, da Paraíba,

Que vem buscar no Recife

Poder morrer de velhice,

Encontra só, aqui chegando,

Cemitério esperando.

Não é viagem o que fazem

Vindo por essas caatingas, vargens;

Aí está o seu erro:

Vem é seguindo seu próprio enterro

O retirante Severino chega ao fundo do desalento. Sua sede de vida começa a parecer-lhe uma rematada loucura. O que pode esperar? Não esperava muita coisa: apenas um pouquinho mais do que o nada que conseguira até agora:

Esperei, devo dizer

Que ao menos aumentaria

Na quartinha, a água pouca,

Dentro da cuia, a farinha,

O algodãozinho da camisa,

Ao meu aluguel com a vida 
Agora, segundo o que dizem os especialistas da morte, só lhe resta aceitar e resignar-se diante do fato segundo o qual, na verdade, desde o sertão, seu próprio enterro seguia. Surpreende-se de estar ainda vivo. O morto ainda está com vida. E começa a pensar na solução do suicídio, a solução de

\author{
Apressar \\ A morte a que se decida \\ E pedir a este rio, \\ Que vem também lá de cima, \\ Que me faça aquele enterro \\ Que o coveiro descrevia: \\ Caixão macio de lama, \\ Mortalha macia e liquida, \\ Coroas de baronesa \\ Junto com flores de anhinga, \\ E aquele acompanhamento \\ De água que sempre desfila \\ (que o rio aqui no Recife \\ não seca, vai toda a vida)
}

Sentado à beira do lamaçal da zona mais pobre da cidade, onde na agua parada se erguem os mocambos, onde o lixo é atirado e a agua contaminada carrega toda espécie de doenças, Severino é interrompido em seus sombrios pensamentos pela chegada de um homem, um carpinteiro - mestre-carpina - chamado José, de Nazaré da Mata.

Severino interroga Jose cheio de desespero, perguntando se a água do rio ali é profunda e se dá para cobrir o corpo de um homem.

Seu Jose, mestre carpina

Para cobrir corpo de homem

Não é preciso muita água.

Basta que chega o abdome

Basta que tenha fundura

Igual à de sua fome

Jose de Nazaré lhe responde que nunca tentou atravessar o rio a nado. E ao perceber a intenção de Severino, fruto de seu desespero, procura dizerlhe palavras de ânimo. Busca mostrar-lhe que a desesperança não conduz a nada e se se deixa que a mesma cresça, se transforma em um mar que invade e afoga a terra inteira. 
Severino retirante

O meu amigo é bem moco

Sei que a miséria é mar largo

Não é como qualquer poço

Mas sei que para cruza-la

Vale bem qualquer esforço...

O mar de nossa conversa

Precisa ser combatido

Sempre, de qualquer maneira

Porque senão ele alarga

E devasta a terra inteira.

Severino insiste com seu desespero, com sua sede abrasiva e angustiante, enquanto o carpina lhe responde com paz e esperança. Mostralhe que luta cada dia para conseguir viver, pois

O que compro a retalho

É, de qualquer forma, vida

Severino não consegue sair de seu vazio existencial e faz a derradeira pergunta ao carpinteiro:

Seu Jose mestre carpina,

Que diferença faria

Se em vez de continuar

Tomasse a melhor saída:

A de saltar, numa noite,

Fora da ponte e da vida?

A resposta é dada não pelo carpina, mas pela anunciação de uma chegada salvadora: uma mulher - qual anjo mensageiro (Malak Yahweh) - sai correndo da casa de Jose e anuncia-lhe que seu filho acaba de nascer

Compadre Jose, compadre

Que na relva estais deitado:

Conversais e não sabeis

Que vosso filho é chegado?

Estais aí conversando

Em vossa prosa entretida;

Não sabeis que vosso filho

Saltou pra dentro da vida? 
Saltou pra dentro da vida

Ao dar o primeiro grito;

E estais aí conversando

Pois sabei que ele é nascido.

A viagem de Severino está perto de acabar. Mas acabar na vida e não na morte. O nascimento de um menino, uma vida nova que acaba de nascer na pobreza e na humildade invade o espaço da morte e traz a vida que canta de alegria nos pobres vizinhos que ajudam a Maria no parto e que louvam a vida que acaba de sair do seu ventre.

Todo o céu e a terra

Lhe cantam louvor

Foi por ele que a maré

Esta noite não baixou...

E este rio de água, cega

Ou baça, de comer terra,

Que jamais espelha o céu

Hoje enfeitou-se de estrelas

Chegam pessoas de todos os lados trazendo presentes para o recémnascido. Ao oferece-los justificam a simplicidade do presente com sua pobreza.

Minha pobreza tal é...

E tal como no Evangelho dos reis magos e do óbolo da viúva ${ }^{43}$ cada um oferece o que tem de melhor: caranguejos pescados nos mangues; o leite que tem no seio para amamentar o filho; papel de jornal para servir de cobertor; agua da bica do Rosário; um canário que canta; um boneco de barro; abacaxi, ostras apanhadas no cais; tamarindos da Jaqueira e jaca da Tamarineira; peixe pescado no Passarinho, carne de boi dos Peixinhos; siris do lamaçal; mangas dos quintais ricos; goiamuns dados pelos pobres. A comunidade põe em comum tudo que possui para que todos sejam irmãos a fim de fazer a todos irmãos de lama, de leite e de ar.

Aparecem duas ciganas que vão profetizar a sorte do menino. Uma faz uma profecia negativa: o que o espera é uma pobreza igual à de todos os que ali estão: catar comida no lixo como as galinhas, mergulhar no lamaçal

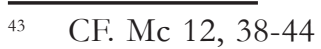


imundo para dele retirar camarão guaiamum, refocinhar como os porcos nos monturos. A segunda faz outro tipo de profecia:

Não o vejo dentro dos mangues

Vejo-o dentro de uma fábrica;

Se está negro não é lama,

É graxa de sua máquina,

Coisa mais limpa que a lama

Do pescador de maré...

Por fim, os vizinhos e todos os que acorreram a visitar o Menino, vão entoar para ele e sua formosura o louvor definitivo. Sua beleza não é tanta de volume de corpo, de peso e de saúde. Mas sim da humanidade que o configura e o faz natural e constitutivamente belo

...tem o peso de homem

na obra de ventre de mulher...

tem a marca de homem,

marca de humana oficina...

...as mãos que criam coisas nas suas já se adivinha.

É belo como o coqueiro

Que vence a areia marinha...

É tão belo como um sim

Numa sala negativa...

Belo porque é uma porta

Abrindo-se em mais saídas

Belo como a última onda

Que o fim do mar sempre adia.

É tão belo como as ondas

Em sua adição infinita

Belo porque tem do novo

A surpresa e a alegria.

Belo como a coisa nova

$\mathrm{Na}$ prateleira até então vazia.

Como qualquer coisa nova

Inaugurando o seu dia.

Ou como o caderno novo

Quando a gente o principia

É belo porque o novo

Todo o velho contagia.

Belo porque corrompe

Com sangue novo a anemia. 
Infecciona a miséria

Com vida nova e sadia

Com oásis o deserto,

Com ventos a calmaria

A vida nova que o Nascimento do Menino trouxe para o desespero de Severino jorrou como agua no deserto. E agora criou um oásis de esperança que o retirante pode habitar. É de novo o carpina Jose que volta a retomar o fio da conversa com o retirante Severino. Retoma então a pergunta que este lhe fizera: se não vale mais saltar fora da ponte e da vida.

Jose demonstra que embora seja difícil defender só com palavras uma vida Severina, a própria vida respondeu

\footnotetext{
Mas se responder não pude

À pergunta que fazia,

Ela, a vida, a respondeu

Com sua presença viva.

E não há melhor resposta

Que o espetáculo da vida:

Vê-la desfiar seu fio

Que também se chama vida,

Ver a fábrica que ela mesma,

Teimosamente, se fabrica,

Vê-la brotar como há pouco

Em nova vida explodida;

Mesmo quando é assim pequena

A explosão, como a ocorrida;

Como a de há pouco, franzina;

Mesmo quando é a explosão

De uma vida Severina.
}

\section{Considerações finais: Severinos somos todos}

O poema de Joao Cabral, na verdade, é um auto de Natal. Descreve a imensa maioria da humanidade debatendo-se na pobreza, na humilhação, na opressão, na carência de quase tudo. Menos de sua dignidade de ser humano. A sede de Deus que Severino sente e que o faz desfiar rosários, rezar ladainhas e caminhar sem parar, atravessando desertos e margeando rios será saciada com a própria vida. Vida que pode ser pobre, franzina, pequena, Severina, mas que é santa e merece louvor e celebração como a que aconteceu no humilde mocambo de Maria e Jose, o mestre-carpina de Nazaré da Mata. 
O deserto que Severino atravessa é como aquele que o povo de Deus um dia cruzou saindo do cativeiro rumo à libertação. A penúria da travessia era tal que os migrantes eram assaltados a toda hora pela tentação de voltar atrás, de voltar ao conforto ilusório do cativeiro e da idolatria para não enfrentar a dureza e o desafio da liberdade. Neste caminhar a saudade de Deus e o desejo de estar junto a ele já o revelavam como a vida que infecciona a morte que procura agredir a criação. A sede que beijava os lábios e os corpos dos filhos de Israel era sede corporal, mas também espiritual. Sede de estar perto da vida e de experimentar a plenitude do Senhor desta mesma vida.

A primeira comunidade cristã disse que a vida se manifestou na encarnação de Deus que se deu plenamente em Jesus de Nazaré.

O que era desde o princípio, o que temos ouvido, o que temos visto com os nossos olhos, o que temos contemplado e as nossas mãos têm apalpado no tocante ao Verbo da vida porque a vida se manifestou, e nós a temos visto; damos testemunho e vos anunciamos a vida eterna, que estava no Pai e que se nos manifestou, que vimos e ouvimos nós vos anunciamos, para que também vós tenhais comunhão conosco. Ora, a nossa comunhão é com o Pai e com o seu Filho Jesus Cristo. ${ }^{44}$

O poema de João Cabral diz que essa manifestação continua a dar-se cada dia, na vida dos pobres que lutam incessantemente pela sobrevivência, que trabalham duramente pelo pão de cada dia. Continua na vida dos migrantes que em seu país ou fora dele procuram alternativas para viver e escapar da morte certa e prematura. Mas que também criam, constroem, cantam, recitam, narram histórias, amam, fazem filhos e os alimentam. ${ }^{45}$

E isso é belo, aí está a verdadeira beleza, a suprema Estética: a do sim na sala negativa, a do caderno novo quando a gente o principia, a da surpresa e da alegria que trazem as coisas novas, a da vida nova e sadia que infecciona a miséria e a desesperança.

É a partir daí que se reconhece a Epifania da salvação para toda a humanidade no mistério da encarnação de Deus, de sua "kenose" que desce até o que é mais desvalido, mais pobre, mais desamparado, mais "Severino" para enche-lo da agua viva que sacia para sempre a sede.

A Teologia latino-americana entendeu essa Vida como a busca fundamental dos pobres. E a esperança nesta Vida apesar da convivência

\footnotetext{
44 Jo $1,1-3$

45 Cf. Gustavo Gutierrez, A força histórica dos pobres, Petrópolis, Vozes, 1981.
} 
diuturna com a morte os faz santos de uma santidade primordial que nada nem ninguém pode matar nem contestar. ${ }^{46}$

Severino é pobre, é migrante em seu próprio país. É vítima da sociedade do descarte, que o Papa Francisco menciona na Fratelli Tutti. É vítima igualmente da negligência da humanidade para com a Criação e a Casa Comum. A lira de João Cabral cantou há mais de meio século as dores e agruras da Vida Severina que a Teologia da Libertação tem denunciado e exposto. E como a vida Severina continua a ser um fato, esse diálogo da teologia com a literatura continua a dar frutos.

\section{Referências}

ACADEMIA BRASILEIRA DE LETRAS. https://www.academia.org.br/academicos/joaocabral-de-melo-neto/biografia\#: : :text=Jo $\%$ C $3 \%$ A $30 \% 20$ Cabral $\% 20 \mathrm{de} \% 20 \mathrm{Melo} \% 20 \mathrm{Neto} \% 20$ nasceu $\% 20$ na $\% 20$ cidade $\% 20$ do $\% 20$ Recife,Foi $\% 20$ recebido $\% 20$ por $\% 20$ Jos $\%$ C $3 \%$ A $9 \% 20$ Am\%C3\%A9rico. Acessada em 20 de outubro de 2020.

BISHOP, Elizabeth. "The Death and Life of a Severino", in Poetry, Vol. 103, No. 1/2, Work in Progress: Long Poems, Sequences (Oct. - Nov., 1963).

BROWN, Sherri; WATER, Cherri. Water imagery and the power and presence of God in the Gospel of John, Theology today 72, 3 (2015).

CAMPOS, Jose Nilson B.; STUDART, Ticiana Marinho de Carvalho. Secas no nordeste do Brasil: origens, causas e soluções, em Fourth Inter-American Dialogue on Water Management, 201, Foz do Igacu, Anais do IV Dialogo Interamericano de Porto Alegre: Associação Brasileira de Recursos Hídricos, 2001, v. 01

CHOUUINARD, Larry. The kingdom of God and the pursuit of justiça in Matthew, Restoration Quarterly, 2003.

CNBB. Carta dos bispos do Piauí sobre a seca, de dezembro de 2012 in http://www.cnbb. org.br/index.php?option $=$ com_content\&view $=$ article\&id $=11158$ : carta-dos-bispos-do-piauisobre-a-seca-1\&catid=156\&Itemid=212 acessado em 7 de marco de 2016.

CODY, Aelred. What the desert meant in Ancient Israel, Studia Missionalia 28 (1970).

DUPONT, Jacques. Les Béatitudes, Paris, J. Gabalda, 1973.

GUTIÈrREZ, Gustavo. A força histórica dos pobres, Petrópolis, Vozes, 1981.

GUTIÉRREZ, Gustavo. Teologia da Libertação, Petrópolis, Vozes, 1971.

http://www.biblestudytools.com/commentaries/jamieson-fausset-brown/matthew/matthew-5. html 10/2/2016.

HUNTER, Malcolm. The Elusive Nomad. God and the Nomads: Highlighting the Biblical Narrative, International Journal of Frontier Missiology, 31: 3 (Fall 2014)

46 Artigo de Jon Sobrino em Concilium numero sobre a santidade. 
diálogo entre a teologia e a poesia de João Cabral de Melo Neto

MEIER, John P. Matthew 5: 3-12, Interpretation, 44 no 3 Jul 1990.

MELO NETO, João Cabral de. Morte e Vida Severina e outros poemas. Rio de Janeiro: Alfaguara/Objetiva: Rio de Janeiro, 2007.

MESTERS, Carlos. Ouvi o clamor do meu povo, Estudos Bíblicos de Mt 5 - 9, in Estudos Bíblicos 26.

MORAIS, DENISE. Bioma Caatinga. http://www.invivo.fiocruz.br/cgi/cgilua.exe/sys/start. htm?infoid=962\&sid=2 acessado em 24 de outubro de 2020 .

NETO, José Elias Pinheiro. Geografia e Literatura: a paisagem geográfica e ficcional em Morte e Vida Severina de João Cabral de Melo Neto, Boletim Campineiro de Geografia. v. 2, n. 2, 2012.

PEREIRA, Marcos Paulo C,; LACHAT, Marcelo (org.) Pelo Sertão, o Brasil, Macapá, UNIFAP, 2016.

RAHNER, Karl. Theological Investigations: More Recent Writings, vol. 4, Darton, Longman \& Todd, 1966.

SOARES, Edmilson. Seca no Nordeste e a transposição do Rio São Francisco, Geografias, Belo Horizonte, 01 de Julho - 31 de Dezembro de 2013. Vol. 9, nº 2, 2013.

SOBRINO, Jon. Jesus na América Latina. Ensaio a partir das vítimas, SP, Loyola, 2000.

TALMON, S. The "desert motif" in the Bible and in Qumran literature, 31-63 in A. ALTMANN (ed) Biblical motifs (Cambridge, Mass,s 1966).

WRIGHT, Tom. Jesus and the Victory of God, Minneapolis, Fortress, 1996.

WYATT, N. Sea and desert: symbolic geography in West Semitic religious thought, UgaritForschungen 19 (1987).

Submetido em: 4-11-2020

Aceito em: 26-11-2020 